\title{
Physiological, Biochemical, and Molecular Changes in Pelargonium Cuttings Subjected to Short-term Storage Conditions
}

\author{
Richard N. Arteca ${ }^{1}$, Jeannette M. Arteca, Tzann-Wei Wang, and Carl D. Schlagnhaufer \\ Department of Horticulture, The Pennsylvania State University, University Park, PA 16802
}

\begin{abstract}
Additional index words. carbohydrate, ethylene, ACC, ACC synthase, ACC oxidase, photosynthesis
Abstract. The purpose of this study was to evaluate physiological, biochemical, and molecular changes that occur in unrooted Pelargonium $\times$ hortorum cuttings during storage. Pelargonium cuttings of 'Sincerity' (good shipper), 'Wendy Ann' (moderate shipper) and 'Snowmass' (poor shipper) were stored at $25^{\circ} \mathrm{C}$ and evaluated over a 5-day period. Following removal from storage, cuttings of all cultivars exhibited steady and significant decline in photosynthesis, respiration, carbohydrate, starch, and protein over time. However, no significant differences were observed among cultivars for all of these parameters. Ethylene levels produced by 'Sincerity' and 'Wendy Ann' began to increase 3 days following storage; whereas, 'Snowmass' showed an increase after 1 day, reaching a peak at 3 days, and then declined. When unrooted cuttings of 'Snowmass' were stored for 5 days at temperatures ranging from 4 to $25^{\circ} \mathrm{C}$, it was observed that those stored at $4{ }^{\circ} \mathrm{C}$ had a significantly higher visual rating, chlorophyll content, and root and shoot weight than at higher temperatures tested. As temperature increased from 10 to $25^{\circ} \mathrm{C}$, quality of cuttings declined. Changes in gene expression of two ACC synthases and an ACC oxidase were evaluated in 'Snowmass' cuttings stored at 4 and $25{ }^{\circ} \mathrm{C}$. Correlations between ethylene and ACC levels with gene expression were observed. Chemical name used: 1aminocyclopropane-1-carboxylic acid (ACC).
\end{abstract}

Production of Pelargoniums for use as cut flowers, bedding plants, and potted plants is a worldwide industry. Wholesale value of vegetatively and seed-propagated Pelargoniums increased by 60\% from 1979 to 1990. In the United States, Pelargoniums account for $17.3 \%$ of all wholesale bedding plant sales. In 1990, Pelargoniums produced from cuttings were valued at almost $\$ 86.5$ million, far more than seed or flat Pelargoniums (Berninger, 1993). To meet the increasing market demand, production and shipment of healthy cuttings and plants are necessary. However, current shipping and storage techniques have had deleterious effects on Pelargonium cuttings. Wilting, chlorosis, necrosis, and abscission of leaves typically follows most shipping and storage procedures (Carrow and Bahnemann, 1980; Kaltaler, 1966; Marousky and Harbaugh, 1981). Chlorotic leaves reduce acceptability of cuttings and promote susceptibility to Botrytis, which readily spreads within shipping containers (Carrow and Bahnemann, 1980). As a result, regrowth of cuttings is also jeopardized following damage in storage (Carrow and Bahnemann, 1980).

Several biochemical changes occur during leaf senescence, including changes in chlorophyll, protein, nucleic acids, respiration, and plant hormones. The most visible evidence of leaf senescence is loss of chlorophyll. Pelargonium cuttings have been shown to become chlorotic when packed and exposed to simulated storage conditions (Kaltaler, 1966; Krebs and Zimmer, 1977). Reports have indicated that proteins are rapidly degraded during senescence before leaf chlorosis (Martin and Thimann, 1972; Mizrahi et al., 1970; Osborne, 1962). It is well documented that many forms of stress stimulate ethylene production, which results in an acceleration of senescence (Abeles et al., 1992). Pelargoniums are ethylene-sensitive flowering plants (Nell, 1993). Storage conditions to reduce ethylene production and maintain quality of plant material, including storage under low pressure, low tempera-

Received for publication 25 Jan. 1996. Accepted for publication 11 July 1996. Contribution no. 317, Dept. of Horticulture, Pennsylvania State Univ. The cost of publishing this paper was defrayed in part by the payment of page charges. Under postal regulations, this paper therefore must be hereby marked advertisement solely to indicate this fact.

'To whom reprint requests should be addressed. ture, and supply of ethylene biosynthesis or action inhibitors such as aminooxyacetic acid, (AOA), aminoethoxyvinylglycine, (AVG), and silver thiosulfate, (STS) have been tested (Eisenberg et al., 1976; Paton and Schwabe, 1987; Purer and Mayak, 1987; Whalen and Wulster, 1991). However, these techniques have produced limited success in maintenance of quality of Pelargoniums during storage. Although applying STS inhibits ethylene action and reduces petal shattering, it is only effective during early storage. Moreover, STS renders plants susceptible to Pythium root rot (Nell, 1993) and reduces root formation (Whalen and Wulster, 1991), and it has been recently banned for commercial use (Oglevee, personal communication). AOA and AVG inhibit ACC synthase activity, while $\mathrm{Co}^{2+}$ inhibits ACC oxidase activity, but these are not used due to phytotoxicity problems (Wang and Arteca, 1992). Temperature control appears to be the most effective method to avoid leaf chlorosis in cuttings and plugs (Nell, 1993), but it is costly and in some cases not practical.

Recently, tomato fruit storage problems have been reduced by transferring RNA antisense ACC synthase or ACC oxidase or RNA sense ACC deaminase into tomato plants (Hamilton et al., 1990; Klee et al., 1991; Oeller et al., 1991). ACC synthase and ACC oxidase genes have been identified in many plants (Kende, 1993), and ACC deaminase was found in bacteria (Klee et al., 1991). Since ACC is the immediate precursor of ethylene, ACC deaminase can remove the amino group of ACC, thereby inhibiting the conversion of ACC to ethylene.

In this study, we evaluated changes in the physiology and biochemistry of unrooted Pelargonium cuttings during storage. We also evaluated changes in two Pelargonium ACC synthase genes (GAC-1, GAC-2) (Wang and Arteca, 1995) and a Pelargonium ACC oxidase gene (GEFE-1) (Wang et al., 1994) following storage. Our ultimate goal is to use antisense technology to reduce shipping injury and storage stress in Pelargonium.

\section{Materials and Methods}

Plant materials. Unrooted Pelargonium $\times$ hortorum 'Sincerity' (good shipper), 'Wendy Ann' (moderate shipper), and 'Snowmass' 
(poor shipper) cuttings were obtained from virus-indexed stock from Oglevee Ltd. (Connellsville, Pa.). Three cuttings were rooted in a 15-cm-diameter standard plastic pot containing growing media and placed on a mist bench in a greenhouse under natural photoperiod. The growing medium contained $184 \mathrm{~g}$ calcitic lime (CON-LIME, Bellefonte, Pa.), 31.4 g KNO (Hummert, St. Louis), $21.2 \mathrm{~g}$ triple superphosphate 0-46-0 (available $\mathrm{P}_{2} \mathrm{O}_{4}$; Hummert), $83.4 \mathrm{~g}$ gypsum $83 \%$ (Hummert), and $4.03 \mathrm{~g}$ fritted trace elements no. 555 (W.R. Grace \& Co., Fogelsville, Pa.) in $100 \mathrm{~L}$ of 4 peat : 2 perlite : 1 soil. The medium was steam-sterilized for at least $4 \mathrm{~h}$ before use. Pots were subjected to a mist ( $6 \mathrm{~s}$ mist every $6 \mathrm{~min}$ ) for $20 \mathrm{~h} \cdot \mathrm{d}^{-1}$ for the first $3 \mathrm{~d}$ then gradually decreased (by $4 \mathrm{~h} /$ week) to $8 \mathrm{~h} \cdot \mathrm{d}^{-1}$ by the fourth week. After 4 to 6 weeks, pots were transferred to a bench without mist, fertilized at every watering with $250 \mathrm{ppm}$ N of 15-16-17 (15N-7.04P-14.1K) fertilizer (W.R. Grace \& Co.) and leached once a week with tap water. Fungicides and pesticides were used as needed. The greenhouse was vented when day temperature reached $26^{\circ} \mathrm{C}$ and was kept at $18^{\circ} \mathrm{C}$ during the night. Plants were grown for another 4 to 6 weeks before use in our experiments.

Eight cuttings (10 to $15 \mathrm{~cm}$ long) were collected from the three cultivars from stock plants grown above, the cut base was wrapped in moist KimPak (Seedburo Equipment Co., Chicago), and cuttings were placed in a partially sealed plastic bag packed in shipping boxes and stored at $25^{\circ} \mathrm{C}$ unless designated otherwise. For all parameters tested in this study, four individual cuttings were used per replication at each sampling date. All experiments were repeated three times.

Measurements of photosynthesis and respiration. A Hansatech LD-2 system (Decagon, Pullman, Wash.) was used in the study. This system measures leaf photosynthesis or respiration by monitoring oxygen production or consumption within a sealed chamber containing a leaf disk. Carbon dioxide concentration was maintained at saturating levels to keep stomates open. Temperature was maintained at $25^{\circ} \mathrm{C}$ in the chamber. Oxygen concentration was measured using a Clark electrode (Decagon), which can detect minute changes in oxygen.

Ethylene and ACC determinations. Ethylene was analyzed with a Hewlett Packard (Valley Forge, Pa.) 5830 dual-column gas chromatograph equipped with $3.175-\mathrm{mm}-\mathrm{od} \times 1.2-\mathrm{m}$ columns packed with activated alumina. Injector port, column, and flame ionization detector temperatures were 90,90 , and $300^{\circ} \mathrm{C}$, respectively (Wang and Arteca, 1992). Three fully expanded leaves (3 to $4 \mathrm{~g}$ fresh weight) were collected from each cutting, placed in a 50$\mathrm{mL}$ vial containing $1 \mathrm{~mL}$ distilled water, sealed with a serum cap, and kept at 4 or $25^{\circ} \mathrm{C}$ in the dark for $2 \mathrm{~h}$ before measuring ethylene.

For ACC analysis, $1 \mathrm{~g}$ of leaf tissue was extracted in $85 \%$ ethanol. The extract was dried, resuspended in $1 \mathrm{~mL}$ of water, and centrifuged at $4500 \times g_{n}$ for $15 \mathrm{~min}$. An aliquot $(300 \mu \mathrm{L})$ was mixed with $0.5 \mathrm{~mL}$ ice-cold $20 \mathrm{~mm} \mathrm{HgCl}_{2}$ in a $13 \times 100$-mm test tube and sealed with a serum cap. For converting ACC to ethylene, $0.2 \mathrm{~mL}$ of an ice-cold mixture of $5 \% \mathrm{NaOCl}$ and $15 \mathrm{M} \mathrm{NaOH}(2: 1 \mathrm{v} / \mathrm{v})$ was injected. The tube was vortexed for $15 \mathrm{~s}$, allowed to incubate for 5 min, and ethylene in the test tube headspace was determined by gas chromatography (Tsai et al., 1988). Remaining leaves were frozen in liquid $\mathrm{N}_{2}$ and stored at $-80{ }^{\circ} \mathrm{C}$ until analyzed.

Total protein, carbohydrate, starch, and chlorophyll determination. Total protein was determined according to Bradford (1976) using bovine serum albumin as a standard. Sucrose, glucose, fructose, and starch were determined according to the manufacturer's protocols using UV-based kits (Boehringer Mannheim Biochemicals, Indianapolis). Chlorophyll was determined according to Witham et al. (1971).
Temperature treatments. 'Snowmass' cuttings were stored at 4, 10,20 , and $25^{\circ} \mathrm{C}$ for $5 \mathrm{~d}$. Following storage, four cuttings from each of the treatments were used for chlorophyll extraction, determining leaf weight per plant, and visual rating, with $5=$ best (dark green and turgid) and $1=$ worst (chlorotic and/or not turgid). The remaining four cuttings from each treatment were planted in soil and grown for $10 \mathrm{~d}$, and then measurements were recorded for leaf weight per plant, root weight, and chlorophyll content. Visual ratings were also made. Two sets of controls were used where one set was sampled before rooting and the other was planted and grown for $10 \mathrm{~d}$.

RNA extraction. RNA was extracted according to Wang and Arteca (1995). Briefly, $15 \mathrm{~g}$ of leaves were ground to a fine powder in liquid $\mathrm{N}_{2}$ and then homogenized in $30 \mathrm{~mL}$ of homogenization buffer $0.2 \mathrm{M}$ Tris, $\mathrm{pH} 9$, containing $5 \mathrm{~m}$ guanidium thiocyanate, $1 \%$ polyvinyl pyrrolidone, $0.62 \%$ sodium Sarkosyl, and $1 \%$ bmercaptoethanol. The homogenate was centrifuged at $3000 \times g_{n}$ at $4{ }^{\circ} \mathrm{C}$ for $20 \mathrm{~min}$. The supernatant was filtered through two layers of MiraCloth (Calbiochem) into a polycarbonate tube and centrifuged at $47,000 \times g_{\mathrm{n}}$ at $4^{\circ} \mathrm{C}$ for $30 \mathrm{~min}$. The supernatant was layered on a $10-\mathrm{mL} 5.7 \mathrm{M}$ of $\mathrm{CsCl}$ cushion and centrifuged at $112,000 \times g_{\mathrm{n}}$ in a SW-28 rotor at $4{ }^{\circ} \mathrm{C}$ for $24 \mathrm{~h}$. After centrifugation, the RNA pellet was collected from the bottom of the tubes as described by Sambrook et al. (1989).

Northern analysis. Total RNA was fractionated on a $1.5 \%$ agarose gel containing $2.2 \mathrm{M}$ formaldehyde. Following electrophoresis, RNA was transferred to a nylon membrane by capillary transfer in $20 \times$ SSC overnight, air dried for $1 \mathrm{~h}$, and fixed by UV exposure. Filters were prehybridized at $42{ }^{\circ} \mathrm{C}$ with a solution containing $6 \times$ SSC, $5 \times$ Denhardt's reagent, $0.1 \%$ SDS, 100 $\mathrm{mg} \cdot \mathrm{mL}^{-1}$ denatured fragmented salmon sperm DNA, and $50 \%$ formamide for $4 \mathrm{~h}$. Hybridization was performed overnight at 42 ${ }^{\circ} \mathrm{C}$ using $1 \times 10^{6} \mathrm{cpm} \cdot \mathrm{mL}^{-1}$ of $G A C-1, G A C$-2, and $G E F E-1$ probes were labeled with ${ }^{32} \mathrm{P}-\mathrm{dCTP}$ using random priming. Membranes were washed at room temperature in $2 \times$ SSC plus $0.1 \%$ SDS for 15 $\min , 2 \times \mathrm{SSC}$ plus $0.1 \% \mathrm{SDS}$ at $62^{\circ} \mathrm{C}$ for $15 \mathrm{~min}$, and $0.2 \times \mathrm{SSC}$ plus $0.1 \% \mathrm{SDS}$ at $62{ }^{\circ} \mathrm{C}$ for $15 \mathrm{~min}$. The blot was exposed to Kodak XAR-5X-ray film with two intensifying screens at $-80{ }^{\circ} \mathrm{C}$ for 24 to $48 \mathrm{~h}$. Blots were rehybridized using a pea ribosomal gene (Jorgenson et al., 1982) to ensure that equal amounts of total RNA were present in each lane.

\section{Results and Discussion}

All three cultivars have exhibited a decline in photosynthetic rate, total protein, starch, sucrose, glucose, and fructose $1 \mathrm{~d}$ following dark storage at $25{ }^{\circ} \mathrm{C}$ (Figs. 1-3). These changes occurred before a reduction in chlorophyll content or respiration rate and before induction of high ethylene levels. This gradual decline for all parameters and cultivars tested, except for ethylene, continued for $5 \mathrm{~d}$ (Figs. 1-3). These findings agree with earlier reports on rapid protein degradation before visible leaf chlorosis (Martin and Thimann, 1972; Mizrahi et al., 1970; Osborne, 1962). In addition, this work agrees with other reports indicating that, when Pelargonium cuttings are packed and exposed to simulated storage conditions, they turn chlorotic (Kaltaler, 1966; Krebs and Zimmer, 1977). 'Snowmass' shows a significant increase in ethylene production $3 \mathrm{~d}$ after storage followed by a decline to undetectable levels by the fifth day. This is in contrast to the observed storage response of 'Sincerity' and 'Wendy Ann' (Fig. 3). It is well documented that many forms of stress stimulate ethylene production, which results in senescence (Abeles et al., 1992). Exogenous applications of ethylene to Pelargoniums during simulated storage conditions have been shown to promote leaf chlorosis (Purer and 
Mayak, 1987). Our results agree with others using different Pelargonium cultivars, whereby a 3 - to 4 -fold increase in ethylene production has been obtained following simulated storage (Purer and Mayak, 1987).

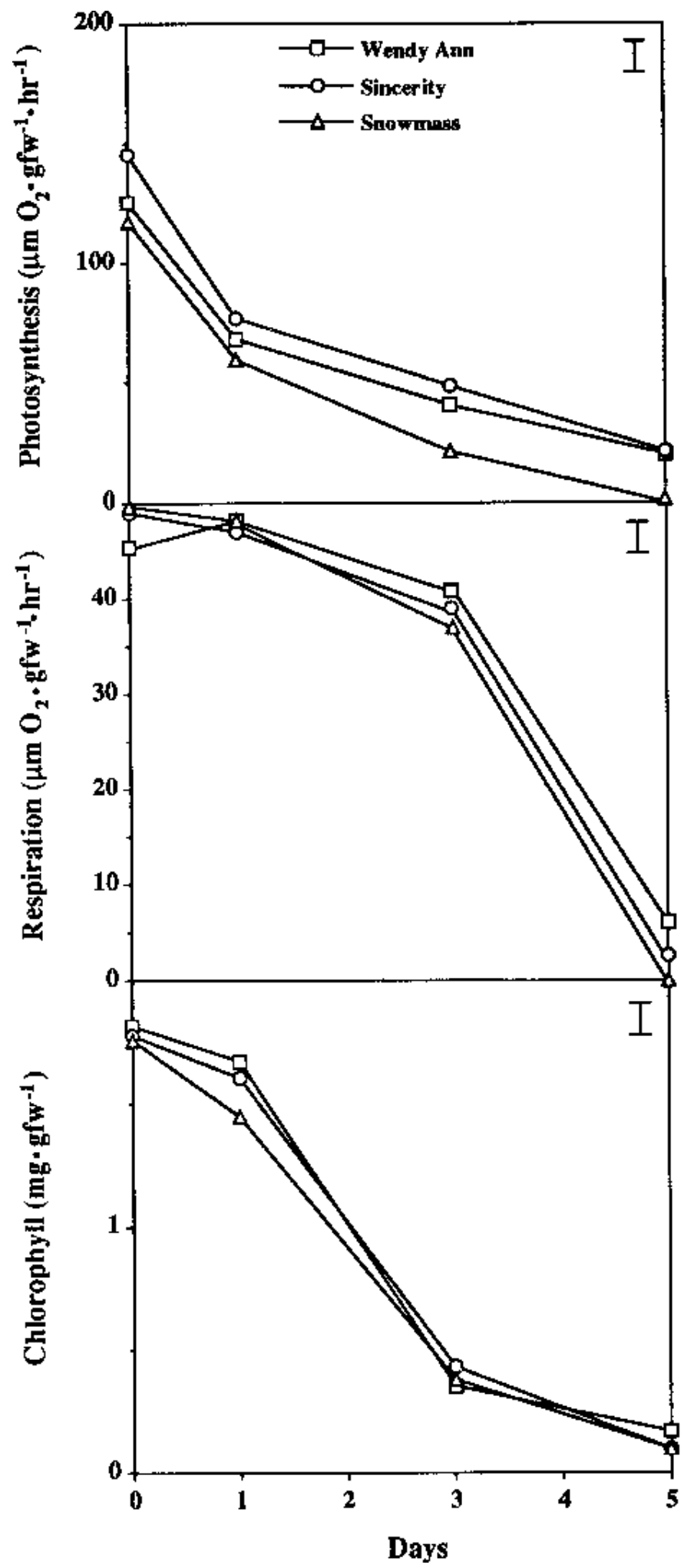

Fig 1. Changes in photosynthesis, respiration, and chlorophyll in Pelargonium 'Sincerity', 'Wendy Ann', and 'Snowmass' cuttings following removal from storage at $25^{\circ} \mathrm{C}$ in the dark. The error bar in the upper right hand corner of each graph corresponds to standard error of the mean.
When 'Snowmass' cuttings were stored at different temperatures from 4 to $25^{\circ} \mathrm{C}$, a gradual decline in visual rating was observed with increasing temperatures (Fig. 4). Leaf weight and chlorophyll content were unchanged at 4 and $10^{\circ} \mathrm{C}$; however, at 20 and $25^{\circ} \mathrm{C}$, leaf weight and chlorophyll content were significantly

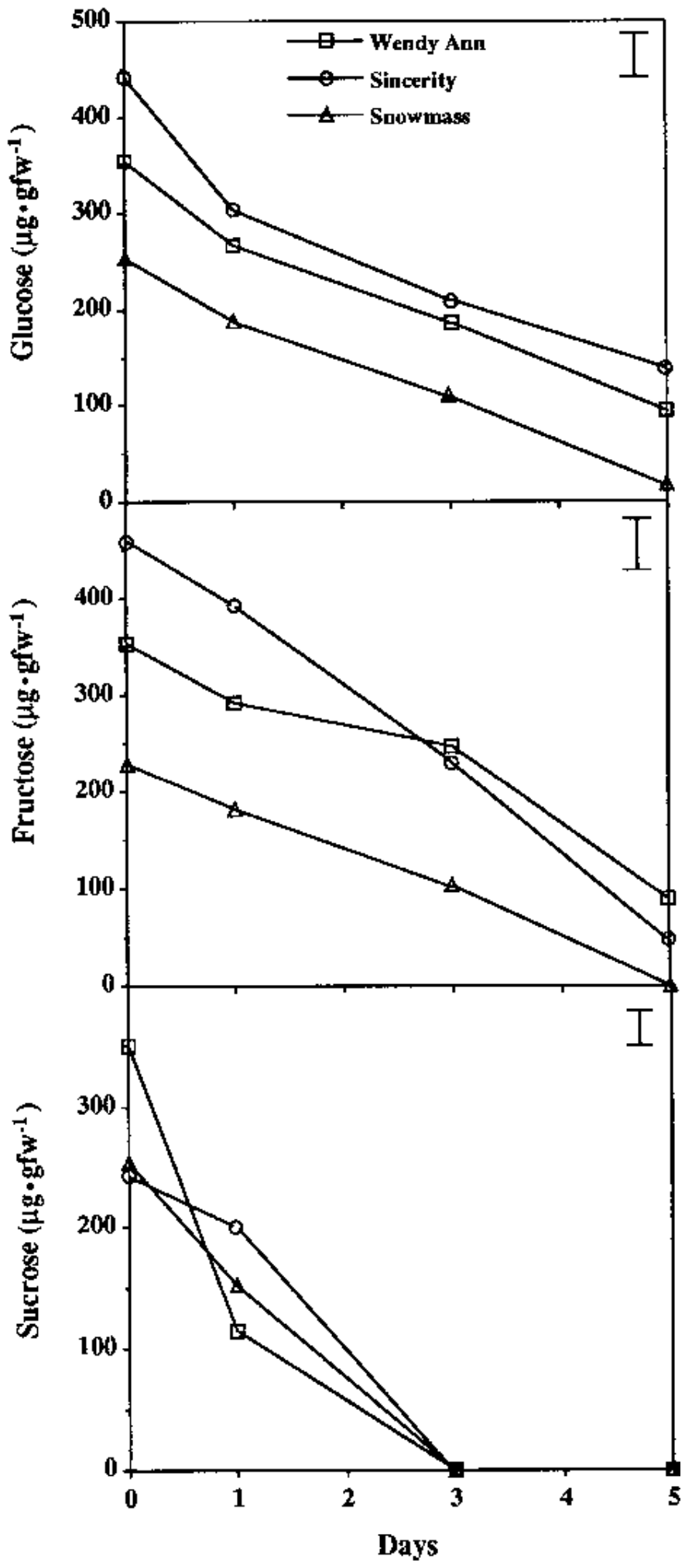

Fig 2. Changes in glucose, fructose, and sucrose in Pelargonium 'Sincerity', 'Wendy Ann', and 'Snowmass' cuttings following removal from storage at $25^{\circ} \mathrm{C}$ in the dark. The error bar in the upper right hand corner of each graph corresponds to standard error of the mean. 
reduced (Fig. 4). When 'Snowmass' cuttings were stored for $5 \mathrm{~d}$ at different temperatures and then planted and allowed to grow for 10 $\mathrm{d}$ before evaluation, there was no difference in visual rating, leaf weight, chlorophyll, and root weight between the $4{ }^{\circ} \mathrm{C}$ treatment

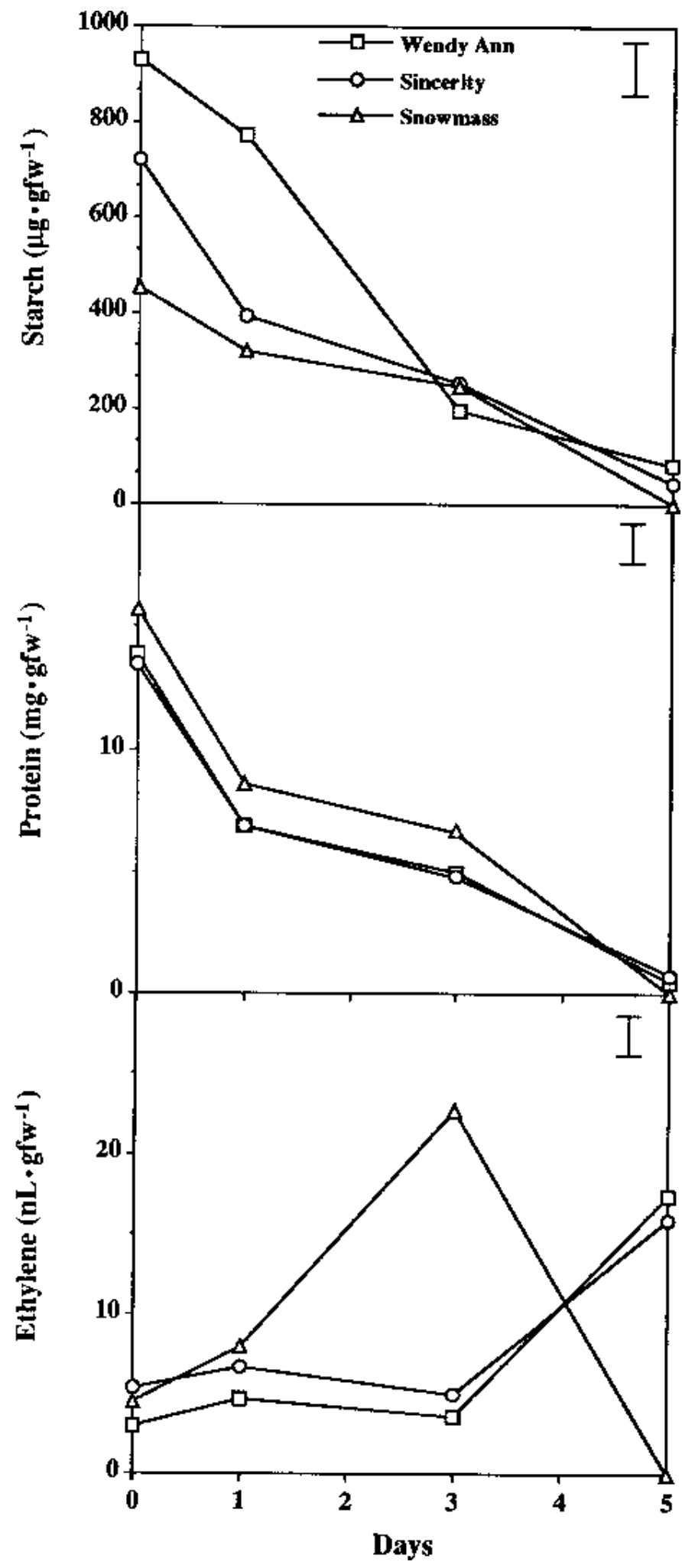

Fig. 3. Changes in starch, protein, and ethylene in Pelargonium 'Sincerity', 'Wendy Ann', and 'Snowmass' cuttings following removal from storage at $25^{\circ} \mathrm{C}$ in the dark. The error bar in the upper right hand corner of each graph corresponds to standard error of the mean. and control. At $10^{\circ} \mathrm{C}$, a reduction in visual rating and root weight was observed; however, there was little difference in leaf weight and chlorophyll content. When cuttings were stored at 20 to $25^{\circ} \mathrm{C}$, there was a significant reduction in all of the parameters tested (Fig. 4). These results were similar to those reporting reduced temperatures were effective in maintaining quality in various cultivars (Nell, 1993).

To characterize the effects of storage on ethylene production in

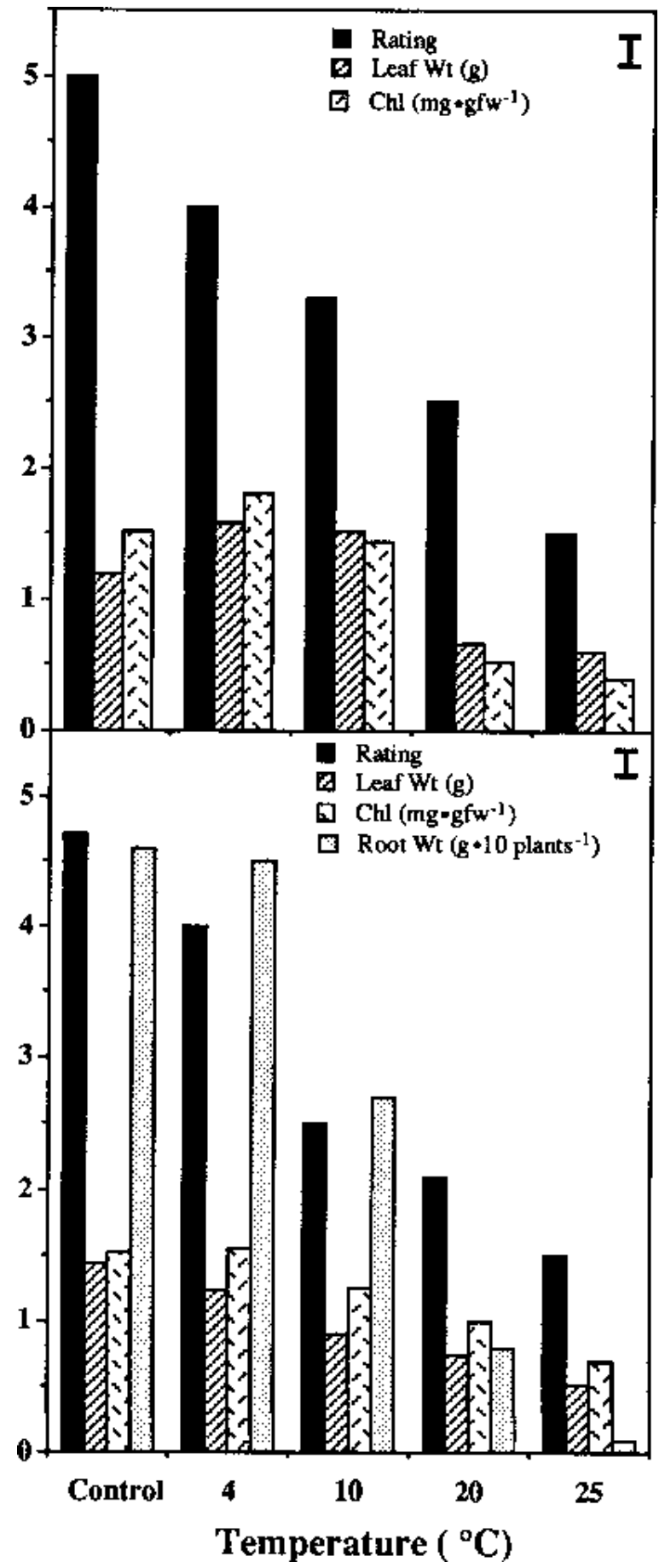

Fig. 4. Changes in visual rating, chlorophyll (Chl), root and leaf weight in Pelargonium 'Snowmass' cuttings after storage in the dark for $5 \mathrm{~d}$ at 4, 10, 20, and $25^{\circ} \mathrm{C}$. A control sample was taken before storage. Following storage, half of the cuttings were evaluated immediately (top) and the other half was planted, grown for $10 \mathrm{~d}$, and then evaluated (bottom). The error bar in the upper right hand corner of each graph corresponds to standard error of the mean. 


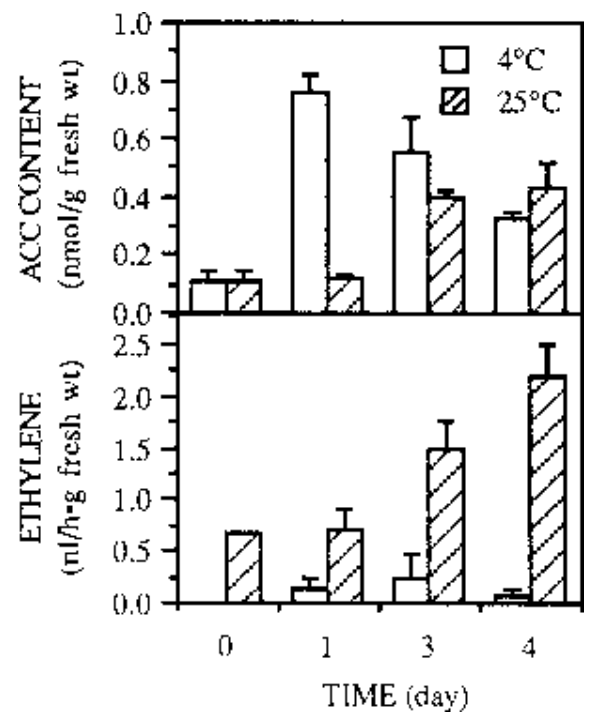

$G A C-2)$, and ACC

oxidase (GEFE-1) gene expression in the poor shipper 'Snowmass'. When 'Snowmass' cuttings were stored at 4 and $25^{\circ} \mathrm{C}, G A C-1$ mRNA was not detected at $4{ }^{\circ} \mathrm{C}$, while it increased 3 to $4 \mathrm{~d}$ following storage at $25^{\circ} \mathrm{C}$ (Fig. 5). One day following storage at $4{ }^{\circ} \mathrm{C}$, there was an increase in $G A C$ - 2 mRNA, while days 3 and 4 were similar to control and correlated with an increase in ACC. $G A C$-2 mRNA levels from cuttings stored at $25^{\circ} \mathrm{C}$ increased $1 \mathrm{~d}$ following storage and to higher levels after 3 to $4 \mathrm{~d}$ in storage, which correlated with increased ethylene and ACC levels. GEFE1 mRNA levels increased in cuttings stored at either 4 or $25^{\circ} \mathrm{C} 1$ $\mathrm{d}$ following storage and to higher levels 3 to $4 \mathrm{~d}$ correlating with increased ethylene and ACC levels (Fig. 5). Since $G A C-1$ and GEFE- 1 have also been induced by water stress (Wang and Arteca, $1995)$ it is likely that they were involved in the production of ethylene and decline in quality following storage.

Worldwide demand for virus-indexed Pelargonium plants and cuttings has increased dramatically over the past 10 years. However, obtaining uniform plants from cuttings and minimizing petal shattering in Pelargoniums that have been shipped long distances or stored for long periods is a major problem, as they are exposed to darkness, transit vibration, water stress, and temperature extremes. Some cultivars are not severely affected and perform well following shipping or storage; whereas, many desirable cultivars are adversely affected resulting in petal shattering, leaf chlorosis, disease developments, and poor rooting. While ethylene in many cases has been implicated in decline in quality of cuttings and petal shattering during short-term shipping or storage, there are no methods available to overcome these adverse effects. Current methods include reduced temperatures, hypobaric storage, ethylene scrubbers, or use of ethylene action blockers or ethylene biosynthesis inhibitors.

The use of antisense technology has been successful in delaying fruit ripening in tomato, which is very sensitive to ethylene (Hamilton et al., 1990; Oeller et al., 1991). Climacteric fruit can be induced to ripen by treatment with ethylene at concentrations above $0.1 \mathrm{~mL}$ of ethylene/L air. It has been shown that the use of antisense technology using the ACC synthase gene can reduce ethylene levels to below $0.1 \mathrm{~nL}$ ethylene/g fruit mass per hour (Oeller et al., 1991). We have shown that Pelargoniums are similar in sensitivity to tomato; therefore, it is likely that this approach will be also useful for Pelargoniums. In this study we have shown that a Pelargonium ACC synthase cDNA (GAC-1) and an ACC oxidase $(G E F E-1)$ are turned on under storage conditions, thereby
Fig. 5. Effects of storage of Pelargonium 'Snowmass' cuttings at 4 and $25^{\circ} \mathrm{C}$ on ACC synthase $(G A C-1$, $G A C-2)$ and ACC oxidase (GEFE-1) over time. Ethylene and ACC levels (left) and Northern analysis (right) with $10 \mu \mathrm{g}$ of total RNA, which were hybridized with $G A C-1, G A C-2$ and $G E F E-1$, and a ribosomal probe as a control.

enabling us to regulate a specific gene that is turned on by shipping and storage stress while allowing other genes required for the production of ethylene during normal plant growth and development to function normally. While the use of antisense technology is no longer novel for use in fruit
ripening, it is novel for delaying leaf and flower senescence in Pelargoniums to produce plants with reduced problems from injury, thereby, increasing the longevity of plants in the home environment.

\section{Literature Cited}

Abeles, F.B., P.W. Morgan, and M.E. Saltveit, Jr. 1992. Ethylene in plant biology. 2nd ed. Academic Press, San Diego.

Berninger, L.M. 1993. Status of the industry, p. 1-2. In: J.W. White (ed.). Geraniums IV. The grower's manual. 4th ed. Ball Publ., Geneva, Ill.

Bradford, M.M. 1976. A rapid and sensitive method for the quantitation of microgram quantities of protein utilizing the principle of protein-dyebinding Anal. Biochem. 72:248-254.

Carrow, B. and K. Bahnemann. 1980. Einflubvon silvernitrat, kinetin und benzylaminopurin auf das vergilben von pelargonium-zonalestecklingen. Gartenbauwissenschaft 6:273-278.

Eisenberg, B.A., G.L. Staby, T.A. Fretz, and T.R. Erwin. 1976. Low pressure storage of rooted and unrooted geraniums. Proc. Intl. Plant Prop. Soc. 26:215-219.

Hamilton, A.J., G.W. Lycett, and D. Grierson. 1990. Antisense gene that inhibits synthesis of the hormone ethylene in transgenic plants. Nature 346: 284-287.

Jorgenson, R.A., R.E. Cuellar, and W.F. Thompson. 1982. Modes and tempos in the evolution of nuclear encoded ribosomal RNA genes in legumes. Carnegie Inst. Wash. Yearbook 81:98-101.

Kaltaler, R.E.L. 1966. Environmental factors and chemical treatments affecting premature senescence of Pelargonium $\times$ hortorum Bailey foliage during shipment. MS thesis. Pennsylvania State Univ., University Park, Pa. p. 99.

Kende, H. 1993. Ethylene biosynthesis Annu. Rev. Plant Physiol. Plant Mol. Biol. 44:283-307.

Klee, H.J., M.B. Hayford, K.A. Kretzmer, G.F. Barry, and G.M. Kishore. 1991. Control of ethylene synthesis by expression of the bacterial enzyme in transgenic tomato plants. Plant Cell 3:1187-1193.

Krebs, O. and K. Zimmer. 1977. Zum problem des welkens and virgilbens von pelargonienstecklingen. Deutscher Gartenbau. 3:84.

Marousky, F.J. and B.K. Harbaugh. 1981. Influence of temperature, light, and ethylene on seedlings of geranium (Pelargonium $\times$ hortorum Bailey) during simulated shipping conditions. J. Amer. Soc. Hort. Sci. 106:527530.

Martin, C. and K.V. Thimann. 1972. The role of protein synthesis in the senescence of leaves. II. The influence of amino acids on senescence. Plant Physiol. 50:432-437.

Mizrahi, Y., J. Amir, and A.E. Richmond. 1970. The mode of action of kinetin in maintaining the protein content of detached Tropaeolum mafus leaves. New Phytol. 69:355-361.

Nell, T.A. 1993. Use and care, p. 171-172. In: J.W. White (ed.). Geraniums IV. The grower's manual. 4th ed. Ball Publ., Geneva, Ill.

Oeller, P.W., M-W. Lu, L.P. Taylor, D.A. Pike, and A. Theologis. 1991. Reversible inhibition of tomato fruit senescence by antisense RNA. Science 254:437-439.

Osborne, D.J. 1962. Effect of kinetin on protein and nucleic acid metabo- 
lism in Xanthium leaves during senescence. Plant Physiol. 37:595-602.

Paton, F. and W.W. Schwabe. 1987. Storage of cuttings of Pelargonium $\times$ hortorum Bailey. J. Hort. Sci. 62:79-87.

Purer, O. and S. Mayak. 1987. Pelargonium cuttings-Effect of growth regulators. Acta Hort. 261:347-354.

Sambrook, J., E.F. Fritsch, and T. Maniatis. 1989. Molecular Cloning: A laboratory manual. Cold Spring Harbor Laboratory, Cold Spring Harbor, N.Y.

Tsai, D.S., R.N. Arteca, J.M. Bachman, and A.T. Phillips. 1988. Purification and characterization of 1-aminocyclopropane-1-carboxylic acid synthase from etiolated mung bean hypocotyls. Arch. Biochem. Biophys. 264:632-640.

Wang, T-W., J.M. Arteca, and R.N. Arteca. 1994. A 1-aminocyclopropane- 1-carboxylate oxidase cDNA sequence from Pelargonium. Plant Physiol. 106:797-798.

Wang, T-W. and R.N. Arteca. 1992. Effects of low $\mathrm{O}_{2}$ root stress on ethylene biosynthesis in tomato plants (Lycopersicon esculentum Mill cv. Heinz 1350). Plant Physiol. 98:97-100.

Wang, T-W. and R.N. Arteca. 1995. Identification and characterization of cDNAs encoding ethylene biosynthetic enzymes from Pelargonium $\times$ hortorum cv. 'Snowmass' leaves. Plant Physiol. 109:627-636.

Whalen, C.S. and G.J. Wulster. 1991. Causes of reduced pathogen tolerance in Pelargonium after application of silver thiosulfate. HortScience 26:1067-1069.

Witham, F.H., D.F. Blaydes, and R.N. Devlin. 1971. Experiments in plant physiology. van Nostrand, New York. 